\title{
The Impact of Horizon 2020 on Innovation in Europe
}

The EU's stagnation on many innovation indicators led to a number of efforts to spur a turnaround. One of most visible projects has been the Horizon 2020 strategy, which devotes unprecedented levels of funding to the promotion of R\&D and innovation. But does this strategy address the right issues to promote innovation? Is Horizon 2020 right to ignore geographical considerations when allocating funding? What policy instruments does Horizon 2020 recommend, and has it led to novel strategies being employed, beyond the increase in R\&D funding? What steps are individual countries taking? Most importantly, what impact is Horizon 2020 actually having on innovation in the EU?

\section{How to Turn on the Innovation Growth Machine in Europe}

Europe maintains lofty ambitions for building its future growth and prosperity and safeguarding its social model through innovation. The European Union carved its ambition to become the most competitive knowledgebased economy in the world into its 2002 Lisbon Strategy. An ambitious target of devoting three per cent of GDP to R\&D by 2010 was set. And in its subsequent Europe 2020 strategy and Innovation Union Flagship, it set out a roadmap for sustainable and inclusive growth that needs to be smart.

Despite this policy of attention to innovation-based growth and R\&D targeting, Europe's performance on innovation remains weak to date. According to the Innovation Union Scoreboard (IUS) indicator, developed by the European Commission in support of its Innovation Union Strategy, ${ }^{1}$ Europe is not doing well. ${ }^{2}$ Europe's gap relative to the US holds across almost all individual in-

* Reinhilde Veugelers acknowledges financial support from KULeuven (GOA/12/003) and FWO Flanders (G.0825.12), as well as the comments received from the participants of the EUROFORUM Conference, June 2013, Leuven, especially Michel Praet and Bruno van Pottelsberghe.

1 IUS is a composite indicator capturing eight dimensions of innovation: Human Resources, Research Systems, Finance, Firm Investment, Linkages, IPR, Innovations and Economic Effects. For the international benchmarking of Europe, it uses information from 12 indicators to assess these eight dimensions.

2 European Commission: Innovation Union Competitiveness report, 2011. dicators that go into the IUS score. This is a reflection of the systemic nature of Europe's failing innovation capacity. Europe's overall (public and private) R\&D-to-GDP ratio currently stands below two per cent, significantly lower than the ratios in the US, Japan, South Korea and Singapore. Furthermore, there are relatively few signs of progress. China is fast catching up and already on par with the EU.

Why is it so hard to improve Europe's innovative performance? Does Europe have the capacity for knowledgebased growth? This contribution takes a close look at the evidence on Europe's innovation performance. We look at heterogeneity across European countries: Do some countries or parts of Europe do better than others? Is there a convergence over time among European countries in innovation capacity along a process of integration? The analysis finds that Europe maintains an innovation system, with a few well performing countries, in which a slow process of convergence is taking place. Within the innovation ecosystem, it is particularly the business sector that generates an innovation deficit, and this business sector deficit is highly persistent over time.

Why does Europe's business sector, despite having some top performers, have a persistently lower innovative capacity on average when compared to the US? We investigate the age and sector composition of Europe's 
business innovation structure and identify the lack of young innovative companies ("yollies") in innovationbased growth sectors as the major source of Europe's persistent lagging business innovation deficit relative to the US. Europe simply has too few yollies in the right sectors, which can form the nucleus for a capacity to shift economies towards new opportunities for growth.

The obvious next issue we examine is why Europe is less capable of nurturing new strong innovative firms in new sectors. What are the major impediments facing innovative firms in new sectors in Europe? We focus on an important impediment that hampers young firms with highly innovative growth projects, namely access to early-stage risk finance.

The paper concludes with some policy implications. What can Europe do to make its ambitions for knowledge-based growth more realistic? A policy agenda that can tackle the systemic deficit is not easy to establish and requires a long-term commitment to support innovation.

\section{Europe's persistent differences in innovation per- formance}

Although integration has resulted in some level of convergence in innovation, the pace of convergence is slow. There still remain substantial country differences, not only in terms of stock of knowledge but also in the varying capacities to leverage knowledge into growth. To assess convergence, we look at the $\sigma$-coefficient, i.e. the coefficient of variation ( $V$ VAR/MEAN). $\sigma$-convergence occurs when the dispersion across a group of economies decreases over time.

In the 2011 IUS exercise, the best performing ("frontier") countries were Sweden, Denmark, Germany and Finland. The weakest group of countries includes most transition economies, including Latvia, Bulgaria, Lithuania and Romania.

As Table 1 shows, the coefficient of variation on the IUS score is high, illustrating the high level of heterogeneity on innovation capacity in Europe. Although it has slightly decreased in the period 2006-2010, reflecting a slow process of $\sigma$-convergence, dispersion remains substantial. This dispersion holds between frontier and "catching-up" countries, as the difference in average scores of both groups demonstrates (see Panel B). Over the time period considered, a slow catching-up has taken place between the catching-up and the frontier countries in Europe, as the gap scores indicate, but the gap remains considerable. Within both groups, however, there is also substantial heterogeneity, particularly in the catching-up countries, as the coefficient of variation indicates (see Panel C). This dispersion has only slightly decreased in the period considered. Furthermore, in the group of frontier countries, the gap between the top five and the rest is highly stable over time.

As the business sector is responsible for most of Europe's R\&D intensity gap relative to the US, and as this shows a persistent time pattern, we further zero in on the heterogeneity and convergence across European countries in the business component of R\&D expenditures.

The heterogeneity in business R\&D performance across European countries is substantial, as the coefficient of variation shows. And although the coefficient of variation has decreased over time, demonstrating $\sigma$-convergence, the pace of convergence is slow.

Overall, the data show the extreme immobility of business R\&D performance in Europe. At the same time,

Reinhilde Veugelers, University of Leuven, Belgium; and Bruegel, Brussels, Belgium.

Michele Cincera, Université Libre de Bruxelles, Belgium.

Rainer Frietsch, Fraunhofer Institute for Systems and Innovation Research, Karlsruhe, Germany.

Torben Schubert, Fraunhofer Institute for Systems and Innovation Research, Karlsruhe, Germany; and Lund University, Sweden.

Christian Rammer, Centre for European Economic Research (ZEW), Mannheim, Germany.

Anita Pelle, University of Szeged, Hungary.

Andrea Renda, Centre for European Policy Studies, Brussels, Belgium.

Jos Leijten, Joint Institute for Innovation Policy, Brussels, Belgium.

Carlos Montalvo, Netherlands Organisation for Applied Scientific Research TNO, Delft, Netherlands. 
Table 1

Heterogeneity and convergence in Europe on innovation performance

\begin{tabular}{|c|c|c|}
\hline IUS & 2006 & 2010 \\
\hline \multicolumn{3}{|l|}{ Panel A: Within Europe ${ }^{1}$} \\
\hline Average Europe & 0.41 & 0.45 \\
\hline Coefficient of variation & 0.43 & 0.40 \\
\hline Top countries & $\begin{array}{l}\text { SE, CH, DK, DE, FI } \\
(0.758-0.638)\end{array}$ & $\begin{array}{l}\mathrm{CH}, \mathrm{SE}, \mathrm{DK}, \mathrm{FI}, \mathrm{DE} \\
(0.831-0.696)\end{array}$ \\
\hline Bottom countries & $\begin{array}{l}\text { BG, LV, TR, RO } \\
(0.159-0.219)\end{array}$ & $\begin{array}{l}\text { LV, TK, BG, LT, RO } \\
(0.201-0.237)\end{array}$ \\
\hline \multicolumn{3}{|c|}{ Panel B: Frontier versus catching-up countries ${ }^{2}$} \\
\hline Average frontier countries & 0.59 & 0.62 \\
\hline Coefficient of variation & 0.20 & 0.19 \\
\hline Average catching-up & 0.30 & 0.34 \\
\hline Coefficient of variation & 0.36 & 0.33 \\
\hline $\begin{array}{l}\text { Gap catching-up/frontier } \\
(=100)\end{array}$ & 0.51 & 0.55 \\
\hline \multicolumn{3}{|c|}{ Panel C: Within frontier; within catching-up ${ }^{3}$} \\
\hline Average frontier countries & 0.59 & 0.62 \\
\hline Top 5 & 0.70 & 0.74 \\
\hline Non-top 5 & 0.52 & 0.55 \\
\hline Average catching-up & 0.30 & 0.34 \\
\hline Former cohesion countries & 0.39 & 0.44 \\
\hline EU13 & 0.29 & 0.33 \\
\hline
\end{tabular}

${ }_{1}$ The range of IUS scores, in brackets, for the group of countries considered includes, in addition to the EU27, Switzerland and accession countries. Due to their small size, we do not report on LU, MT, CY, MK and IC. ${ }^{2}$ The catching-up countries include the EU13, the four former cohesion countries, the other transition countries and Turkey. There are 13 frontier countries (AT, BE, DK, FI, FR, DE, IT, LU, NL, NO, SE, CH, UK). ${ }^{3}$ The Top 5 countries are CH, SE, $\mathrm{DE}, \mathrm{Fl}$ and DK; former cohesion countries are ES, PT, IE and EL.

So urce: Own calculations based on Innovation Union Scoreboard, 2011.

there is substantial heterogeneity within Europe, which goes beyond the divide between old and new member states and also involves countries like Greece at the bottom. The process of structural change and convergence/ catching up within Europe is very slow, as indicated by the very stable rankings of European countries over time on business R\&D performance.

\section{Age and sectoral composition effects on Europe's business $R \& D$ deficit}

The continued business R\&D deficit is central in Europe's innovation deficit. It is a symptom of its low capacity for both structural change and a shift towards new growth areas. What explains this business R\&D deficit? Why does Europe's business sector have less innovative capacity on average when compared to the
Table 2

\section{Business R\&D expenditures in Europe}

Business R\&D as \% of GDP

\begin{tabular}{lcl} 
& 2004 & \multicolumn{1}{c}{2008} \\
\hline Average EU27 & 1.16 & \multicolumn{1}{c}{1.21} \\
\hline Coefficient of variation & 0.98 & \multicolumn{1}{c}{0.86} \\
\hline Top countries & $\mathrm{SE}, \mathrm{Fl}, \mathrm{CH}$ & $\mathrm{Fl}, \mathrm{SE}, \mathrm{CH}, \mathrm{DK}$ \\
& $(2.63-2.14)$ & $(2.76-2.01)$ \\
\hline Bottom countries & $\mathrm{BG}, \mathrm{TK}, \mathrm{PL}, \mathrm{LT}$, & $\mathrm{BG}, \mathrm{LV}, \mathrm{EL}, \mathrm{RO}$ \\
& $\mathrm{EL}, \mathrm{LV}, \mathrm{RO}$ & $(0.10-0.17)$ \\
& $(0.12-0.21)$ & \\
\hline
\end{tabular}

Source: Own calculations based on Innovation Union Scorecard, 2010.

US, despite its top performers? And why is this deficit so persistent? In line with O'Sullivan, Aghion et al. and others, this contribution claims that Europe's persistent business innovation gap is correlated with its industrial structure. ${ }^{3}$ New firms fail to play a significant role in the innovation dynamics of European industry, especially in the high-tech sectors. This is illustrated by their inability to enter the market, and more importantly, for the most efficient innovative entrants to grow to world leadership. The churning that characterises the creative destruction process in a knowledge-based economy encounters significant obstacles in the EU, suggesting barriers to growth for new innovating firms that ultimately weaken Europe's growth potential. Bartelsman et al. found that post-entry performance differs markedly between Europe and the US, ${ }^{4}$ which suggests the importance of barriers to company growth. This inability of new European firms to grow large seems to manifest itself particularly in the high-tech, high-growth sectors, most notably the ICT sector. This correlates with the European economy's lower degree of specialisation in the R\&D-intensive, high-growth sectors of the 1990s, again most notably the ICT sectors. ${ }^{5}$

This structural European innovation deficit story, related to company age and the sectoral make-up of the economy, has recently attracted much attention. It has been

3 M. O'Sullivan: The EU's R\&D deficit and innovation policy, report of the Expert Group on Knowledge for Growth, European Commission, Brussels 2008; P. Aghion, E. Bartelsman, E. Perotti, S. Scarpetta: Barriers to exit, experimentation and comparative advantage, RICAFE2 WP 056, London School of Economics, 2008.

4 E. Bartelsman, J. Haltiwanger, S. Scarpetta: Microeconomic evidence of creative destruction in industrial and developing countries, Tinbergen Institute Discussion Papers 04-114/3, Tinbergen Institute, 2004.

5 P. Moncada-Paterno-Castello, C. Ciupagea, K. Smith, A. Tubke, M. Tubbs: Does Europe perform too little corporate R\&D? in: Research Policy, Vol. 39, 2009, pp. 523-536. 
investigated in more detail in Veugelers and Cincera, ${ }^{6}$ in which the JRC-EC-IPTS Industrial R\&D Scoreboard figures of global R\&D expenditures of leading innovators by age cohort and sector are decomposed. ${ }^{7}$ Their analysis confirms that the major source of Europe's lagging business innovation deficit relative to the US is the lack of yollies, i.e. young companies that have grown into worldleading innovators, in new innovation-based growth sectors.

The age composition of Europe's leading innovators

Among the US leading innovators in the Industrial R\&D Scoreboard, more than half are "young" (i.e. born after 1975), qualifying them as yollies. US yollies include Microsoft, Cisco, Amgen, Oracle, Google, Sun, Qualcomm, Apple, Genzyme and Ebay. By contrast, in Europe only one out of five leading innovators is "young". Yollies account for 35 per cent of total business R\&D in the US, while in Europe this figure is a mere seven per cent!

The R\&D intensity of European leading companies, whether old or young, is on average smaller than the world average, particularly in comparison to the US. With the US benchmarked at 100, Europe's overall R\&D intensity gap score is 63 per cent. This gap holds both for older companies ("ollies") and yollies. But the difference is more pronounced for yollies. While the R\&D intensity gap score for Europe's ollies is 80 per cent, the score for yollies is 43 per cent.

The lower overall R\&D intensity of Europe's leading innovators can thus be explained by the combination of the following facts:

- Europe has fewer yollies than the US. This matters because yollies have a higher level of R\&D intensity when compared to ollies.

- Europe-based yollies are less R\&D-intensive than their US counterparts.

- European ollies are also less R\&D-intensive than their US counterparts.

As the difference in RDI between Europe and the US is small for ollies, the most important factor in Europe's overall RDI deficit is related to yollies: not only that Eu-

6 R. Veugelers, M. Cincera: Europe's Missing Yollies, Bruegel Policy Brief 2010/06, Bruegel, Brussels 2010; R. Veugelers, M. Cincera: Young Leading Innovators and EU's R\&D intensity gap, Bruegel Policy Contribution 2010/09, Bruegel, Brussels 2010.

7 European Commission: The 2008 EU Industrial R\&D Investment Scoreboard, 2008.
Table 3

EU and US sector specialisation of R\&D activities in innovation-based growth sectors

\begin{tabular}{lcc} 
& EU & US \\
\hline Aerospace \& defence & 1.50 & 1.13 \\
\hline Biotechnology & 0.32 & 2.20 \\
\hline Computer hardware \& computer services & 0.08 & 1.39 \\
\hline Health care equipment \& services & 0.70 & 1.86 \\
\hline Internet & 0 & 2.54 \\
\hline Pharmaceuticals & 1.27 & 1.16 \\
\hline Semiconductors & 0.50 & 1.72 \\
\hline Software & 0.51 & 2.05 \\
\hline Telecommunications equipment & 1.38 & 1.09 \\
\hline All IBG sectors & 0.89 & 1.43 \\
\hline
\end{tabular}

Note: Revealed technological advantages (RTAs) are calculated as the share of the region in total sectoral $R \& D$ relative to the share of the region in overall R\&D. An RTA value higher than 1 reflects that the region is technologically specialised in this sector.

Source: Based on R. Veugelers, M. Cincera: Young Leading Innovators and EU's R\&D intensity gap, Bruegel Policy Contribution 2010/09, Bruegel, Brussels 2010.

rope has fewer of them, but also that the yollies that Europe has are less R\&D-intensive than their US counterparts.

The sectoral composition of Europe's leading innovators

To analyse the sectoral composition problem for explaining Europe's lagging business R\&D deficit, we look at the sectors in which Europe specialises its R\&D activities. We are particularly interested in Europe's position in the sectors that offer the largest scope for knowledge-based growth. To this end, we identify sectors that have (i) an above-average level of R\&D intensity, (ii) an above-average R\&D growth rate and/or (iii) an aboveaverage share of young companies among their leading innovators. This set of sectors includes aerospace, biotechnology, computer hardware \& services, health care equipment \& services, internet, pharmaceuticals, semiconductors, software, and telecom equipment. These are all sectors in the ICT and the health realms. We label these sectors "innovation-based growth sectors" (IBG sectors).

Table 3 shows Europe's R\&D positions in the IBG sectors in which it specialises. When looking at the individual IBG sectors, Europe only has revealed technological advantages (RTAs) in aerospace, pharmaceuticals and telecom equipment, of which only the latter is a "young" 
sector. The US, by contrast, specialises in all IBG sectors. $^{8}$

Europe's sectoral composition, i.e. its failure to specialise in the sectors with the biggest opportunities for knowledge-based growth, not only explains Europe's overall lagging R\&D performance. It can also explain why Europe's young leading innovators are underperforming on R\&D. It is not because European yollies are less R\&D-intensive when compared to their US counterparts in the same sectors (the so-called intrinsic effect). Rather, it is because European yollies operate primarily in less R\&D-intensive sectors (the so-called structural effect).

Table 4 shows that Europe has significantly fewer of its yollies in the sectors with the greatest opportunities for innovation-based growth. In the Internet sector, Europe does not have a single company that has achieved "Leading Innovator" status. In biotechnology, as well, Europe has fewer yollies when compared to the US. Both of these sectors thus serve to illustrate Europe's inability to raise young innovators to leading status in sectors with high innovation-based growth potential (structural effect). But the young innovators it has in these sectors are as R\&D-intensive as their US counterparts, if not even more so. This holds particularly in the ICT sectors. Table 4 thus confirms that the lower R\&D intensity of Europe's Young Leading Innovators, when compared to their US counterparts, is due to a structural, sectoral composition effect, namely Europe's lack of presence in the innovation-based growth sectors. ${ }^{9}$

\section{Explaining Europe's age and sectoral structural in- novation deficit}

Why are there fewer companies starting up and growing into world-leading innovators that spend sufficient resources on R\&D to make it onto the Scoreboard of the largest R\&D spenders? And why is this happening relatively less often, compared to the US, in new technology-based sectors, particularly biotechnology and ICT?

The most frequently cited explanation for the differences in dynamic structure between Europe and the US is a greater willingness on the part of US financial markets to

8 Europe specialises its R\&D in sectors characterised as medium R\&Dintensive (see P. Moncada-Paterno-Castello, C. Ciupagea, K. Smith, A. Tubke, M. Tubbs, op. cit.). These include automobiles, chemicals, electrics, industrial machinery and telecom services. All of them are older, medium R\&D-intensive sectors. Furthermore, automobiles, chemicals and electrics are sectors with belowaverage R\&D growth.

9 See also R. Veugelers, M. Cincera: Europe's Missing ..., op. cit.
Table 4

Yollies in innovation-based growth sectors

\begin{tabular}{lcc} 
& Europe & US \\
\hline Share of yollies in IBG sectors & 62 & 84 \\
\hline RDI of yollies in IBG sectors & 13.9 & 12.6 \\
\hline RDI of region in IBG sectors & 12.0 & 10.0 \\
\hline
\end{tabular}

Source: Based on R. Veugelers, M. Cincera: Young Leading Innovators and EU's R\&D intensity gap, Bruegel Policy Contribution 2010/09, Bruegel, Brussels 2010.

fund the growth of new companies in new sectors. ${ }^{10}$ Evidence from the German Community Innovation Survey confirms the importance of financial constraints for innovating companies in general, and particularly for young innovating companies. ${ }^{11}$ Young highly innovative companies report on average higher obstacles to innovation than other innovating firms. Financial constraints - both internal and external - are the main barriers to innovation for young highly innovative companies. Although this also holds for other innovating firms, the differential is largest for younger companies. Cincera, Ravet and Veugelers examine econometrically the financial constraints faced by world-leading R\&D investors. ${ }^{12}$ Their analysis confirms that over the last decade, younger leading innovators appear to be more affected by financing constraints than their older counterparts, particularly in the EU.

Although the evidence clearly supports the importance of access to finance for highly innovative growth projects, the evidence also shows that one can nevertheless not ignore the importance of other impediments to innovation which reduce the expected rates of return on R\&D investments. These other barriers relate to problems in the demand for innovations, regulatory burdens, access to skills and problems in partnering..$^{13}$ Cincera and Veugelers examine econometrically the rates of return to R\&D investments for world-leading R\&D investors. ${ }^{14}$ They find that, while young firms in the US succeed in realising significantly higher rates of return to $\mathrm{R} \& \mathrm{D}$ as compared to their older counterparts, European

10 M. O'Sullivan, op. cit.

11 C. Schneider, R. Veugelers: On Young Highly Innovative Companies: why they matter and how (not) to policy support them, in: Industry and Corporate Change, Vol. 19, No. 4, 2010, pp. 969-1007.

$12 \mathrm{M}$. Cincera, J. Ravet, R. Veugelers: R\&D financing constraints of younger aged leading innovators in the EU and the US, in: Economics of Innovation and New Technology, forthcoming.

13 C. Schneider, R. Veugelers, op. cit.

$14 \mathrm{M}$. Cincera, R. Veugelers: Differences in the rates of return to R\&D for European and US Young Leading R\&D firms, in: Research Policy, Vol. 43, No. 8, 2014, pp. 1413-142. 
firms fail to generate significant rates of return, even if they are yollies and even if they are in high-tech sectors.

All this is a strong reminder that the innovation deficit in Europe is systemic. Access to finance cannot be tackled in isolation but should be embedded in an innovation environment that also addresses the other barriers to innovation. As these other barriers reduce the expected rates of return on highly innovative projects, they affect the appetite of financers to provide funds for these projects.

\section{Recommendations for innovation policy making in Europe}

The evidence presented in this contribution has important implications for Europe's innovation policy agenda. The evidence suggests that policies aimed at raising $R \& D$ expenditure across all types of industries and companies does not address the root causes of Europe's innovation deficit. To do this, policies need to address the specific barriers to development of new high R\&Dintensity sectors and companies, as the evidence has shown how pivotal these sectors and companies are for tackling Europe's innovation deficit.

What types of policy interventions are needed in Europe to address these specific barriers? And how targeted do they need to be? A first important remark is that a general innovation policy aimed at improving the environment for innovation remains necessary. Because yollies need to interact with other innovators, and because innovators should not be impeded while they mature, a policy to address the lack of young companies in young R\&Dintensive sectors needs to fit into a comprehensive innovation policy. This innovation policy should further the integration of the European capital, labour, product and services markets; make it easier for players in the innovation system to interact; and, at the same time, ensure healthy competition.

Such a comprehensive innovation policy will be necessary, but it will not be sufficient. Policy measures are also needed to tackle the specific barriers faced in new sectors by new companies. This includes inter alia access to external financing for fast-growing, highly innovative projects, through public funding and/or by leveraging private risk funding. First and foremost, the fragmentation in the EU venture capital (VC) market should be addressed: the critical size for a viable, fluid, thick European VC market can only be reached when VC markets operate at an integrated European scale and are open to the world. Beyond furthering the single market for risk financing, a system of grants for high-risk, innovative projects by young companies during their critical startup and development stages - when financial market barriers are at their highest - cannot be missing in the set of EU instruments.

At this stage of the analysis, when there are still too many unknowns about whether and which interventions are effective for which countries, policy makers are advised to engage in close monitoring of emerging innovative markets. This will help to determine whether the right mix of policy instruments is present in the country and if the mix is effective for ensuring the smooth development of companies in new markets. Furthermore, policies that are shown to be ineffective in other markets can be adapted or abandoned altogether. Monitoring should include a strong prospective angle, able to identify new emerging markets well in advance so that a proactive policy mix can be identified for the very earliest phases of development, when the risk of market failure is at its highest.

\section{Heterogeneity of Innovation Systems in Europe and Horizon 2020}

The US is still the most important national science and research system in the world, with China quickly catching up - not only in terms of quantity, but also in terms of quality. Europe, however, as the largest transnational science and research system, is ahead of these national systems. Recent analysis suggests that the European Union as a whole overtook the US with respect to the per- formance of the science system. ${ }^{1}$ This is not only due to

1 European Commission: Innovation Union Scoreboard 2014, Brussels 2014; C. Rammer, B. Aschhoff, D. Crass, T. Doherr, M. Hud, C. Köhler, B. Peters, T. Schubert, F. Schwiebacher: Innovationsverhalten der deutschen Wirtschaft - Indikatorenbericht zur Innovationserhebung 2013, Centre for European Economic Research (ZEW), Mannheim 2014. 